\title{
Campylobacter pylori: clinical, histological, and serological studies
}

\author{
C MUSGROVE, ${ }^{*}$ F J BOLTON, $\dagger$ A M KRYPCZYK, ${ }^{*}$ J M TEMPERLEY, $\ddagger$ A CAIRNS, \\ W G OWEN, ${ }^{*}$ D N HUTCHINSON†
}

From the Departments of *Histopathology and + Microbiology, District Laboratory, Preston, and the Department of $\ddagger$ Medicine, Royal Preston Hospital, Preston

SUMMARY The presence of Campylobacter pylori, histologically diagnosed gastritis, and antibodies to $C$ pylori were determined in a series of 113 patients undergoing endoscopy. Paired biopsy specimens from the fundus, body, and antrum were collected from 59 patients and from the antrum of 54 patients. The presence of $C$ pylori was confirmed by either culture or silver stain in 30 of 59,31 of 59 , and 54 of 103 biopsy specimens from the fundus, body, and antrum, respectively. Of the specimens which contained $C$ pylori 20 of $30(66 \%)$ from the fundus, 25 of $31(80 \%)$ from the body, and 54 $(100 \%)$ from the antrum showed gastritis. $C$ pylori and gastritis were shown in seven of nine $(78 \cdot 1 \%)$ of patients with gastric ulcers and in nine of $11(82 \%)$ of patients with duodenal ulcers. Using an enzyme linked immunosorbent assay (ELISA) technique to detect IgG antibody to $C$ pylori, all patients with histologically diagnosed gastritis and organisms present had titres of $\geqslant 640$; eight of 39 $(21 \%)$ of patients without gastritis and without organisms gave similar titres. Hence the presence of $C$ pylori was associated with gastritis and with raised titres of IgG antibody.

Spiral organisms have been described in the stomach of man and other animals by several authors since the $1920 \mathrm{~s}^{1-5}$ Following the reports of Warren ${ }^{6}$ and Marshall ${ }^{7}$ there has been an increase in interest in the organism which these authors named $C$ pyloridis and which has since been redesignated $C$ pylori. ${ }^{8}$ These Campylobacter-like organisms and others ${ }^{9}$ have been isolated from gastric biopsy specimens using techniques which were developed for the isolation of intestinal campylobacters.

Despite the profusion of short reports there have been few detailed substantiative prospective studies, especially in Great Britain. We therefore present the results of our study in which 113 patients were investigated endoscopically, histologically, bacteriologically and serologically. Part of this study was designed to determine the distribution of Campylobacter-like organisms in infected or colonised stomachs, an aspect which has not clearly been established. The survey was also undertaken so that we could substantiate the association of these organisms with histologically diagnosed gastritis, gastric, and duodenal peptic ulceration. Furthermore, we inves-

Accepted for publication 11 July 1988 tigated the value of an enzyme linked immunosorbent assay (ELISA) technique for detecting the antibody response in patients included in the survey.

\section{Material and methods}

A series of 113 patients with a clinical indication for upper gastrointestinal endoscopy, originating from outpatient and inpatient referrals over three months in 1984 was studied. These patients comprised 71 men and 42 women with an age range of 19-91 years. The patients had a variety of symptoms relating to the upper gastrointestinal tract, most commonly, epigastric pain or dyspepsia, or both, and some presented with an acute gastrointestinal haemorrhage.

\section{ENDOSCOPY AND SAMPLING PROCEDURES}

A $10 \mathrm{ml}$ sample of blood was taken from each patient for serological tests, immediately before the endoscopy procedure. Biopsy specimens were obtained using biopsy forceps which had been disinfected in $2 \%$ glutaraldehyde and rinsed in distilled water. From the first 59 patients paired biopsy specimens from three sites were taken in the following order: gastric fundus, body, and antrum. In the remaining 54 patients paired biopsy specimens from the antrum only were 
obtained. Examination of the duodenum was undertaken last to avoid contamination of the endoscope with intestinal bacteria.

\section{HISTOLOGY}

One biopsy fragment from each site was fixed immediately in $10 \%$ neutral buffered formalin, then processed routinely, and embedded in paraffin wax. Paired $5 \mu \mathrm{m}$ sections were cut and stained with haematoxylin and eosin and by a silver impregnation method (Warthin-Faulkner). ${ }^{10}$

Histological assessment of the stained sections was made independently by two histopathologists and included: (i) type and thickness of mucosa; (ii) presence or absence of chronic gastritis; and (a) whether quiescent or active in type, and (b) whether superficial or full thickness gastritis, using the guidelines of Whitehead ${ }^{11}$; (iii) glandular atrophy; (iv) intestinal metaplasia; ( $v$ ) presence and distribution of Campylobacter-like organisms.

\section{BACTERIOLOGY}

The other biopsy specimen of any pair was placed into a dry sterile bijoux bottle and transported to the laboratory where it was cultured within two hours of collection. The biopsy specimens were bisected with sterile forceps and the freshly cut surface inoculated on to blood and chocolate agars. These plates were incubated microaerobically at $37^{\circ} \mathrm{C}$ for up to five days. Isolates were confirmed as $C$ pylori by colonial morphology, Gram stain morphology, electron microscopy, positive catalase, oxidase and urease reactions, negative nitrate and hippurate reactions, resistance to nalidixic acid ( $30 \mu \mathrm{g}$ disc) and sensitivity to cephalothin $(30 \mu \mathrm{g}$ disc $)$.

\section{SEROLOGY}

The antigen for the ELISA test was prepared from six strains of $C$ pylori grown on chocolate agar, incubated microaerobically at $37^{\circ} \mathrm{C}$ for three to four days. The growth was harvested into $10 \mathrm{ml}$ of sterile saline, mixed for one minute on a vortex mixer, centrifuged at $3000 \mathrm{rpm}$ for 15 minutes and the supernatant retained. Thiomersal was added to a final concentration of $0.01 \%$ and the antigen stored at $4^{\circ} \mathrm{C}$. This antigen was diluted 1 in 400 and used to determine the titre of antibodies to $C$ pylori by a conventional ELISA technique. $^{12}$

\section{Results}

\section{HISTOLOGY}

One hundred and eight of the 113 patients examined gave satisfactory biopsy specimens for analysis and these comprised 59 from whom multiple site specimens were taken and 49 from whom antral specimens only
Table 1 Histologically assessed inflammation in gastric biopsy specimens

\begin{tabular}{|c|c|c|c|}
\hline \multirow[b]{2}{*}{ Type of gastritis } & \multicolumn{3}{|c|}{ Percentage of specimens showing gastritis } \\
\hline & $\begin{array}{l}\text { Fundus } \\
(n=59)\end{array}$ & $\begin{array}{l}\text { Body } \\
(n=59)\end{array}$ & $\begin{array}{l}\text { Antrum } \\
(n=103)\end{array}$ \\
\hline $\begin{array}{l}\text { None } \\
\text { Superficial gastritis }\end{array}$ & 63 & 52 & 40 \\
\hline $\begin{array}{l}\text { Active } \\
\text { Quiescent }\end{array}$ & $\begin{array}{r}7 \\
20\end{array}$ & $\begin{array}{r}5 \\
29\end{array}$ & $\begin{array}{l}13 \\
12\end{array}$ \\
\hline $\begin{array}{l}\text { Full thickness gastrit } \\
\text { Active } \\
\text { Quiescent }\end{array}$ & $\begin{array}{l}7 \\
3\end{array}$ & $\begin{array}{l}5 \\
7\end{array}$ & $\begin{array}{l}20 \\
10\end{array}$ \\
\hline Not assignable* & $\mathbf{0}$ & 2 & 5 \\
\hline
\end{tabular}

*Specimens showing gastritis but of insufficient thickness to subclassify further.

were taken. Five of the 59 patients in the first series had previously had a partial gastrectomy and therefore it was not possible to collect biopsy specimens from the antrum. The 108 patients studied yielded a total of 59 biopsy specimens from the fundus and body and 103 from the antrum.

Some specimens were of insufficient depth to differentiate between superficial and full thickness inflammation and were termed "not assignable". Full thickness gastritis was not always accompanied by glandular atrophy or intestinal metaplasia. Activity of inflammation implied high numbers of polymorphs in the lamina propria or within the epithelium. The results (table 1) showed an increase in the prevalence of gastritis, in particular full thickness gastritis and active gastritis, towards the antrum. In the first series 14 cases showed glandular atrophy and two cases showed intestinal metaplasia at one or more sites. In the second series three cases showed intestinal metaplasia.

Campylobacter-like organisms shown by silver stain were curved or spiral rods, and within any individual biopsy specimen the distribution of these

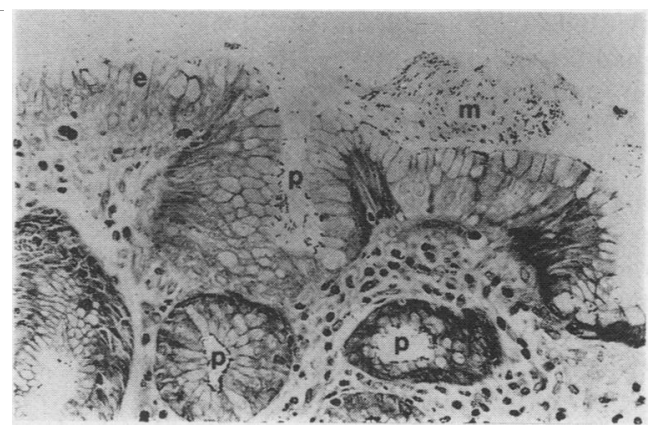

Fig 1 General view of superficial gastric mucosa. Campylobacter-like organisms are seen within surface mucus $(m)$, distributed along the surface epithelium (e), and within lumen of gastric pits ( $p)$. (Warthin-Faulkner). 


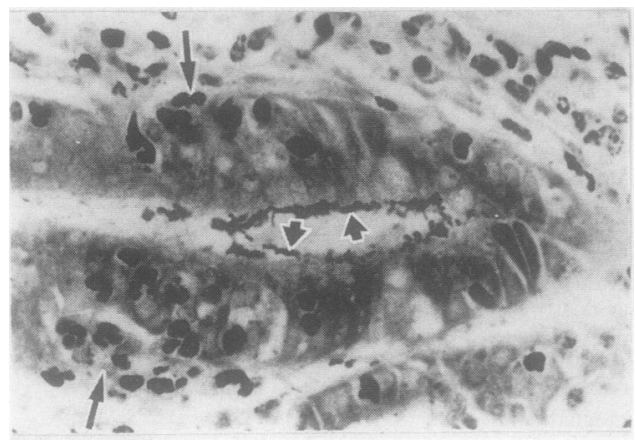

Fig 2 Demonstration of Campylobacter-like organisms within a gastric pit closely related to the surface of epithelial cells (short arrows). Neutrophil polymorphs (long arrows) are infiltrating the glandular epithelium. (WarthinFaulkner).

organisms was patchy. They were often seen lying close to the surface epithelium, within and beneath surface mucus, and sometimes were seen around the intercellular margins of surface epithelial cells. They were most densely distributed within the lumen of the gastric pits (figs 1 and 2). Much less often they extended into the lumen of deeper glands. There were no convincing intracellular organisms, and none was seen in the lamina propria.

\section{DETECTION OF CAMPYLOBACTER-LIKE}

ORGANISMS AND DENSITY OF COLONISATION

Detection of Campylobacter-like organisms in biopsy specimens was determined by their presence in silver stained sections or by culture (table 2). Silver stain alone or culture alone failed to detect Campylobacterlike organisms in a few cases, possibly reflecting patchy distribution of the organisms or poor quality of the biopsy specimen. When the results of silver staining and culture are combined then all or none of the multiple site biopsy specimens (first series) from an individual case contained organisms.

Qualitative assessment of Campylobacter-like organisms grown from biopsy specimens showed that there was a trend of increasing numbers of organisms towards the antrum (fig 3). Thirty per cent of culture positive biopsy specimens from the fundus produced a heavy $(t+t)$ or moderate $(t+)$ growth of Campylobacter-like organisms compared with $60 \%$ from the body and $78 \%$ from the antrum.

\section{ASSOCIATION BETWEEN GASTRITIS AND} PRESENCE OF CAMPYLOBACTER-LIKE ORGANISMS Of those biopsy specimens from the fundus, body, and antrum which contained Campylobacter-like organisms 20 of 30,25 of 31 , and 54 of 54 , respectively, showed gastritis (table 2). Antral biopsy specimens containing Campylobacter-like organisms were three
Table 2 Association between histological gastritis and presence of Campylobacter-like organisms

Percentage of specimens containing Campylobacterlike-organisms

\begin{tabular}{|c|c|c|c|c|}
\hline $\begin{array}{l}\text { Biopsy site } \\
\text { and } \\
\text { inflammation }\end{array}$ & $\begin{array}{l}\text { Detected } \\
\text { by silver } \\
\text { stain }\end{array}$ & $\begin{array}{l}\text { Detected by } \\
\text { culture }\end{array}$ & $\begin{array}{l}\text { Total } \\
\text { detected by } \\
\text { either } \\
\text { method }\end{array}$ & $\begin{array}{l}\text { Not detected } \\
\text { by either } \\
\text { method }\end{array}$ \\
\hline \multicolumn{5}{|l|}{$\begin{array}{l}\text { Fundus } \\
(n=59)\end{array}$} \\
\hline $\begin{array}{l}\text { Gastritis } \\
\text { No gastritis }\end{array}$ & $\begin{array}{l}30 \\
14\end{array}$ & $\begin{array}{l}29 \\
15\end{array}$ & $\begin{array}{l}34 \\
17\end{array}$ & $\begin{array}{r}3 \\
46\end{array}$ \\
\hline \multicolumn{5}{|c|}{ Body $(n=59)$} \\
\hline $\begin{array}{l}\text { Gastritis } \\
\text { No gastritis }\end{array}$ & $\begin{array}{l}41 \\
10\end{array}$ & $\begin{array}{r}42 \\
9\end{array}$ & $\begin{array}{l}42 \\
10\end{array}$ & $\begin{array}{r}5 \\
43\end{array}$ \\
\hline \multicolumn{5}{|c|}{$\begin{array}{l}\text { Antrum } \\
(n=103)\end{array}$} \\
\hline $\begin{array}{l}\text { Gastritis } \\
\text { No gastritis }\end{array}$ & $\begin{array}{r}50 \\
0\end{array}$ & $\begin{array}{c}46^{*} \\
0\end{array}$ & $\begin{array}{c}52 \dagger \\
0\end{array}$ & $41^{7 \ddagger}$ \\
\hline
\end{tabular}

* Ninety eight specimens cultured.

†Includes four specimens that were not cultured.

fIncludes one specimen that was not cultured.

times more likely to show full thickness gastritis than superficial gastritis and twice as likely to show active rather than quiescent inflammation. Campylobacterlike organisms were seen in the absence of gastritis in 10 of 37 fundal biopsy specimens and six of 31 body biopsy specimens. In none of the three sites was there any consistent relation between subjectively assessed degree of inflammation and density of colonisation by organisms. Gastritis in the absence of organisms was? present in two of $59(3 \%)$, three of $59(5 \%)$, and seven of $103(7 \%)$ of biopsy specimens from the gastric fundus, body, and antrum, respectively.

\section{ASSOCIATION BETWEEN OTHER GASTRIC}

\section{FINDINGS AND PRESENCE OF CAMPYLOBACTER-}

LIKE ORGANISMS

Biopsy specimens from the fundus which contained Campylobacter-like organisms were twice as likely to show glandular atrophy as those without organisms; the corresponding figure was one and a half times for

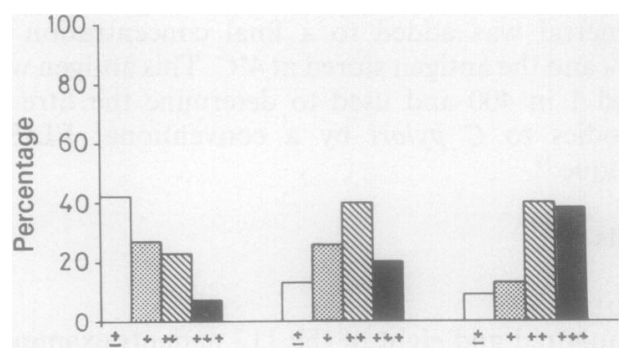

Fig 3 Qualitative growth estimates of Campylobacter-like organisms in biopsy specimens from the gastric fundus, body, and antrum. 
Table 3 Comparison of endoscopy findings with the presence or absence of Campylobacter-like organisms in 108 patients

\begin{tabular}{|c|c|c|}
\hline \multirow[b]{2}{*}{ Endoscopy findings } & \multicolumn{2}{|c|}{ Percentages of patients in each group } \\
\hline & $\begin{array}{l}\text { Campylobacter-like } \\
\text { organisms detected }\end{array}$ & $\begin{array}{l}\text { Campylobacter-like } \\
\text { organisms not detected }\end{array}$ \\
\hline $\begin{array}{l}\text { Normal }(n=29) \\
\text { Duodenitis } \\
(n=21)\end{array}$ & $\begin{array}{l}39 \\
57\end{array}$ & $\begin{array}{l}61 \\
43\end{array}$ \\
\hline $\begin{array}{l}\text { Bile reflux }(n=22) \\
\text { Gastritis }(n=52)\end{array}$ & $\begin{array}{l}50 \\
50\end{array}$ & $\begin{array}{l}50 \\
50\end{array}$ \\
\hline $\begin{array}{l}\text { Partial } \\
\text { gastrectomy } \\
(\mathrm{n}=5)\end{array}$ & 80 & 10 \\
\hline $\begin{array}{l}\text { Gastric ulcer } \\
(n=9)\end{array}$ & 78 & 22 \\
\hline $\begin{array}{l}\text { Duodenal ulcer } \\
(\mathrm{n}=11)\end{array}$ & 82 & 18 \\
\hline
\end{tabular}

the body; no excess was seen in antral biopsy specimens. Intestinal metaplasia was present in six specimens (five subjects). All showed variable degrees of gastritis, and although one of these contained Campylobacter-like organisms, the organisms were absent from areas of intestinal metaplasia. Biopsy specimens taken from sites remote from gastric and duodenal ulcers contained Campylobacter-like organisms in seven of nine and nine of 11 cases, respectively, and these also showed gastritis at all or most sites. Campylobacter-like organisms were present in five $(100 \%)$ of fundal biopsy specimens and in four of five $(75 \%)$ of body biopsy specimens from cases of partial gastrectomy and were associated with variable degrees of gastritis, of no specific type.

\section{ASSOCIATION BETWEEN ENDOSCOPY FINDINGS AND PRESENCE OF CAMPYLOBACTER-LIKE ORGANISMS}

Of the 108 patients investigated, five had a previous partial gastrectomy, nine had a gastric ulcer, and 11 had a duodenal ulcer. In these patients there was a definite association between the endoscopy findings and the presence of Campylobacter-like organisms (table 3). Patients with endoscopically normal gastric mucosa were more likely to have specimens without Campylobacter-like organisms. Patients with bile reflux or endoscopically diagnosed gastritis were found equally likely to yield biopsy specimens with or without Campylobacter-like organisms.

\section{SEROLOGY}

IgG titres determined by an ELISA method are shown in table 4. All of the patients with histologically diagnosed gastritis and Campylobacter-like organisms detected had IgG titres of $\geqslant 640$. Only eight of thirty nine $(21 \%)$ of patients without gastritis and without Campylobacter-like organisms gave similar titres. Similarly, all patients with duodenal or gastric ulcers and Campylobacter-like organisms detected had IgG titres of $\geqslant 640$ whereas only one of four patients with ulceration but without Campylobacterlike organisms gave a similar titre.

\section{Discussion}

This study differed from other prospective studies in that multiple biopsy specimens were taken from the three different areas of the stomach. There was excellent correlation between histological identification and isolation of organisms from paired specimens, a finding in accord with previous studies. ${ }^{1314}$ The few cases in which small numbers of organisms were seen histologically and were not cultured may represent patchy distribution as described by Goodwin et al. ${ }^{13}$ The morphology and location of the organisms was similar to the descriptions by Warren ${ }^{6}$ and Jones et al. ${ }^{14}$ In agreement with these workers, intracellular organisms were not seen; nor were organisms definitely shown within the mucus of epithelial cells as reported by Meyrick-Thomas et $a l .{ }^{15}$ The distribution around the luminal margin of cells, however, was as shown by Phillips et al. ${ }^{16}$

The overall proportion of antral biopsy specimens $(52 \%)$ positive for Campylobacter-like organisms, determined by cultural and histological techniques, was of the same order as most other reports which range between $42 \%$ and $66 \%$, although in two larger series of 300 and 222 patients the respective identification rates were $39 \%$ and $35 \% .{ }^{817}$ In the present study and in common with other workers we have found that

Table 4 IgG serum antibody titres to $C$ pylori in endoscopy patients

\begin{tabular}{|c|c|c|c|}
\hline \multirow[b]{2}{*}{ Patient category } & \multicolumn{3}{|c|}{$\begin{array}{c}\text { Percentage of patients with } \\
\text { ELISA IgG titres }\end{array}$} \\
\hline & $\leqslant 320$ & 640 & $\geqslant 1280$ \\
\hline \multicolumn{4}{|l|}{ Gastritis $\dagger$} \\
\hline $\begin{array}{l}\text { Campylobacter-like } \\
\text { organisms detected } \\
(\mathbf{n}=59)\end{array}$ & 0 & 7 & 93 \\
\hline $\begin{array}{l}\text { Campylobacter-like } \\
\text { organisms not detected } \\
(n=9) \\
\text { Gastritis absent }\end{array}$ & 44 & 33 & 23 \\
\hline $\begin{array}{l}\text { Campylobacter-like } \\
\text { organisms detected } \\
(\mathbf{n}=1)\end{array}$ & 100 & 0 & 0 \\
\hline $\begin{array}{l}\text { Campylobacter-like } \\
\text { organisms not detected } \\
(n=39) \\
\text { Duodenal or gastric ulcer }\end{array}$ & 79 & 8 & 13 \\
\hline $\begin{array}{l}\text { Campylobacter-like } \\
\text { organisms detected } \\
(\mathbf{n}=16)\end{array}$ & 0 & 12 & 88 \\
\hline $\begin{array}{l}\text { Campylobacter-like } \\
\text { organisms not detected } \\
(n=4)\end{array}$ & 75 & $\mathbf{0}$ & 25 \\
\hline
\end{tabular}

*Titres expressed as reciprocals † Histologically diagnosed 
there was a clear association between the presence of organisms and histological gastritis. In the antrum Campylobacter-like organisms were detected in 54 $(88 \%)$ of the 61 biopsy specimens showing gastritis but were not detected in the $\mathbf{4 3}$ with normal morphology. This high correlation between gastritis and the presence of organisms did not extend to the body and fundus, where 16 of $59(27 \%)$ of fundal and 11 of 59 $(19 \%)$ of body biopsy specimens which were not inflamed contained Campylobacter-like organisms. In similar patients, however, Rathbone ${ }^{18}$ and Goodwin $e t$ $a l^{19}$ reported that gastritis was usually present somewhere in the stomach, and in our series this was so in all but two subjects. One of these had had a partial gastrectomy: in the other subject, who had no serological evidence of infection, there was a very small number of organisms in the biopsy specimens, perhaps representing contamination during collection or an early primary infection. In another series Rollason et $a P^{0}$ were unable to find any association between the degree of colonisation by organisms and the severity of gastritis, and our results accord with that observation. Marshall and Warren ${ }^{21}$ have linked activity of gastritis with colonisation by Campylobacter-like organisms but their series comprised mainly antral biopsy specimens. Our findings suggest that this limited sampling may have led to an overestimation of the prevalence of active inflammation in association with colonisation by Campylobacter-like organisms.

In our series a group of histological features, described by Dixon et al, ${ }^{22}$ were seen in a few cases with endoscopically diagnosed bile reflux but only in the absence of Campylobacter-like organisms as reported by O'Connor et $a .^{23}$ There was, however, reflux associated with a very active or quiescent gastritis in almost equal numbers of cases with and without Campylobacter-like organisms present. Attention has been drawn to the absence of Campylobacter-like organisms in biopsy specimens showing intestinal metaplasia, ${ }^{1319}$ and in all but one of the six cases in the present study organisms were not detected. Only a small number of patients with peptic ulceration or partial gastrectomy for previous peptic ulceration were included in this series but at $80 \%$ the association of Campylobacter-like organisms and coexistent gastritis with peptic ulceration was of the same order as in other reports. 2124

In our study there was excellent correlation between the presence of Campylobacter-like organisms, gastritis, and raised titres of IgG antibody ( $\geqslant 640$ by ELISA). A similar finding has also been shown by Jones et al $^{14}$ and McNulty et al ${ }^{26}$ using complement fixation tests, and this would suggest that the application of serodiagnosis to gastritis associated with Campylobacter-like organisms could result in a reduced need for endoscopy. In three of five patients with IgG titres of $\geqslant 640$ and gastritis but in whom Campylobacter-like organisms were not shown, multiple biopsy specimens had been collected, and in each subject gastritis was observed only at one site. These findings help to confirm the concept of patchy distribution of gastritis and probably also patchy distribution of organisms. In the present study IgG titres of $\geqslant 640$ were found in all patients with Campylobacter-like organisms, gastric or duodenal ulcers, and gastritis at some location in the stomach, whereas in a similar study Marshall et al, ${ }^{27}$ using a passive haemagglutination test, $93 \%$ of such patients had high titres of antibody.

Neither the symptoms of the patients investigated nor the endoscopic findings showed any correlation with the presence (or absence) of $C$ pylori. Although there is excellent correlation between the presence of $C$ pylori, gastritis, peptic ulceration and raised IgG antibody titres, the clinical importance of Campylobacter-like organisms in the aetiology of gastric illness has not been defined. This subject has, however, been widely discussed in many papers and extensively reviewed..$^{19}$ To date, the most persuasive evidence of an aetiological role is the attempt to fulfil Koch's postulates by ingesting a culture of Campylobacterlike organisms after first inducing hypochlorhydria. ${ }^{28}$ Under physiological conditions, however, both gastritis and Campylobacter-like organism colonisation may be secondary to some other factor which is less operative at a distance from the antrum, thus accounting for the variable distribution and density of the colonisation and associated gastritis in other sites.

\section{References}

1 Lim RKS. A parasitic spiral organism in the stomach of the cat. Parasitology 1920;12:108-12.

2 Edkins JS. Spirella regaudi in the cat. Parasitology 1923;15: 296-307.

3 Cowdrey EV, Scott GH. Effect on monkeys of small doses of a concentrated preparation of viosterol. Archives of Pathology 1936;1:1-23.

4 Doenges JL. Spirochaetes in the gastric glands of Macacus rhesus and of man without related disease. Archives of Pathology 1939;27:469-77.

5 Vial JD, Orrego $H$. Electron microscope observations on the fine structure of parietal cells. J Biophys Biochem Cytol 1960;7: 367-72.

6 Warren JR. Unidentified curved bacilli on gastric epithelium in active chronic gastritis. Lancet 1983; i:1273.

7 Marshall BJ. Unidentified curved bacilli on gastric epithelium in active chronic gastritis. Lancet 1983;i:1273-5.

8 Marshall BJ, Goodwin CS. Revised nomenclature of Campylobacter pyloridis. Int J Syst Bacteriol 1987;37:68.

9 Kasper G, Dickgiesser N. Isolation from gastric epithelium of campylobacter like bacteria that are distinct from "Campylobacter pyloridis'. Lancet 1985; i:111-2.

10 Culling CFA. In: Handbook of histopathology techniques, 2nd ed. London: Butterworths. 1963:325.

11 Whitehead R. In: Mucosal biopsy of the gastro intestinal tract 3rd ed. Philadelphia: W B Saunders, 1984:41-58. 
12 Voller A, Bidwell DE, Bartlett A. The enzyme linked immunosorbent assay (ELISA): a guide with abstracts of microplate applications. Guernsey: Summerfield House, 1979.

13 Goodwin CS, Blincow ED, Warren JR, Waters TE, Sanderson CR, Easton L. Evaluation of cultural techniques for isolating Campylobacter pyloridis from endoscopic biopsies of gastric mucosa. J Clin Pathol 1985;38:1127-31.

14 Jones DM, Lessells AM, Eldridge J. Campylobacter-like organisms in the gastric mucosa: culture, histology and serological studies. J Clin Pathol 1984;37:1002-6.

15 Meyrick-Thomas J, Poynter D, Gooding C, et al. Gastric spiral bacteria. Lancet 1984;ii:100.

16 Philips AD, Hine KR, Holmes GKJ, Woodings DF. Gastric spiral bacteria. Lancet 1984;ii:100-1.

17 Booth L, Holdstock G, MacBride H, et al. Clinical importance of Campylobacter pyloridis and associated serum IgG and IgA antibody responses in patients undergoing upper gastrointestinal endoscopy. J Clin Pathol 1986;39:215-19.

18 Rathbone BJ, Wyatt JI, Worsley BW, Trijdosiewic LK, Heatly RV, Locowsky MS. Immune Response to Campylobacter pyloridis. Lancet 1985;i:1217.

19 Goodwin CS, Armstrong JA, Marshall BJ. Cambylobacter pyloridis, gastritis and peptic ulceration. J Clin Pathol 1986;39:353-65.

20 Rollason TP, Stone J, Rhodes JM. Spiral organisms in endoscopic biopsies of the human stomach. J Clin Pathol 1984;37:23-6.

21 Marshall BJ, Warren JR. Unidentfied curved bacilli in the stomach of patients with gastritis and peptic ulcer. Lancet 1984;i:311-4.

22 Dixon MF, O'Connor HJ, Axon ATR, King RFGJ, Johnson D. Reflux gastritis-a distinct histopathological entity? $J$ Clin Pathol 1986;39:524-30.

23 O'Connor HJ, Wyatt JI, Dixon MF, Axon ATR. Campylobacterlike organisms and reflux gastritis. J Clin Pathol 1986;39:531-4.

24 Marshall BJ, McGechie DB, Rogers PA, Glancy RJ. Pyloric campylobacter infection and gastroduodenal disease. Med $J$ Aust 1985;142:439-44.

25 Lambert JR, Dunn KL, Eaves RL, Korman MG, Hansky J, Punkard K. Pyloric CLO in the human stomach. Med J Aust 1985;143:174.

26 McNulty CAM, Crump B, Gearty J, et al. The distribution of and serological response to campylobacter pyloridis in the stomach and duodenum. In: Pearson AD, Skirrow MB, Lior H, Rowe B, eds. Campylobacter III. PHLS: London, 1985: 174-5.

27 Marshall BJ, McGechie DB, Graham JF, Utley PJ. Pyloric campylobacter serology. Lancet 1984;ii:281.

28 Marshall BJ, Armstrong JA, McGechie DB, Glancy RJ. Attempt to fulfill Koch's postulates for pyloric campylobacter. Med J Aust 1985;142:436-9.

Requests for reprints to: Dr D N Hutchinson, Director, Public Health Laboratory, Royal Infirmary, Meadow Street, Preston PR1 6PS, Lancs. 